\title{
Pentraxin 3 - possible uses in neonatology and paediatrics
}

\author{
Pentraksyna 3 - możliwości zastosowania w neonatologii i pediatrii
}

Department of Neonatology, Chair of Gynaecology and Obstetrics, Faculty of Medical Sciences in Katowice, Medical University of Silesia in Katowice, Katowice, Poland

Correspondence: Department of Neonatology, Chair of Gynaecology and Obstetrics, Kornel Gibiński University Clinical Centre of the Medical University of Silesia in Katowice, Medyków 14, 40-752 Katowice, Poland, tel.: +48570 032 632, e-mail: mszymkowiak@sum.edu.pl

Abstract Pentraxin 3 (PTX3) is a multifunctional acute phase protein belonging to the family of long pentraxins, which is synthesised in numerous cells of the body under the influence of proinflammatory factors and locally at the site of inflammation. Under physiological conditions, PTX3 is stored in neutrophil granules, where there is a constant pool of glycoproteins. Increased pentraxin 3 levels in blood serum are observed as early as 1 hour after a damaging stimulus. Elevation of PTX3 serum levels can be used to diagnose fertility disorders in women as well as in pregnancy pathology, women at risk of pre-eclampsia, gestational diabetes, premature rupture of membrane and preterm delivery. The biological function of PTX3 is not fully understood, especially in the population of newborns and children. So far, no reference values for PTX3 levels in newborns and children have been developed. This protein can be used as a marker of pulmonary hypertension in newborns as well as to assess the degree of respiratory failure in premature infants. In older children, it is useful in the assessment of the severity of meningococcal disease and sepsis as well as in the treatment of childhood asthma. There are studies available in which blood levels of PTX3 significantly correlate with the severity of kidney damage in Henoch-Schönlein macular degeneration in children, and the evaluation of this protein in urine is used to detect renal parenchymal destruction after pyelonephritis.

Keywords: pentraxin 3, newborn, acute-phase proteins

Streszczenie Pentraksyna 3 (PTX3) jest wielofunkcyjnym białkiem ostrej fazy należącym do rodziny długich pentraksyn, którego synteza zachodzi w licznych komórkach organizmu pod wpływem czynników prozapalnych oraz lokalnie, w miejscu zapalenia. W warunkach fizjologii PTX3 jest magazynowana w ziarnistościach neutrofili, gdzie znajduje się stała pula glikoproteiny. Wzrost stężenia PTX3 w surowicy krwi obserwuje się już godzinę po zadziałaniu bodźca uszkadzającego. Ocena stężenia PTX3 w surowicy może służyć do diagnostyki zaburzeń płodności u kobiet, a także być wykorzystywana w patologii ciąży, u kobiet zagrożonych stanem przedrzucawkowym, cukrzycą ciężarnych, przedwczesnym odpłynięciem płynu owodniowego i porodem przedwczesnym. Funkcja biologiczna PTX3 nie jest do końca poznana, szczególnie w populacji noworodków i dzieci. Dotychczas nie opracowano wartości referencyjnych stężenia PTX3 u noworodków i dzieci. Białko to można wykorzystywać jako marker nadciśnienia płucnego u noworodków, a także do oceny stopnia niewydolności oddechowej wcześniaków. U starszych dzieci PTX3 jest przydatna w ocenie nasilenia choroby meningokokowej i posocznicy, a także w trakcie leczenia astmy dziecięcej. W literaturze można znaleźć prace, w których stężenie PTX3 we krwi istotnie koreluje z zaawansowaniem uszkodzenia nerek w przebiegu plamicy Schönleina-Henocha u dzieci, a pomiar stężenia tego białka w moczu służy do wykrywania destrukcji miąższu nerek po przebytym zapaleniu odmiedniczkowym.

Słowa kluczowe: pentraksyna 3, noworodek, białka ostrej fazy 


\section{INTRODUCTION}

$\mathrm{P}$ entraxin 3 (PTX3), also known as tumour necrosis factor (TNF) or TNF-stimulated gene 14 (TSG 14), is an acute phase protein with pleiotropic properties, which belongs to a phylogenetically conservative subfamily of long pentraxins. The name derives from the pentameric structure of proteins. Pentraxin 3 was discovered and first described by Ferruccio Breviario in $1992^{(1)}$. Human PTX3 is a glycoprotein composed of $381 \mathrm{ami-}$ no acids, which contains a unique $\mathrm{N}$-terminal domain and a C-terminal domain common for long and short pentraxins, which contains the eight amino acid pentraxin signature sequence identical for all pentraxins ${ }^{(1)}$. Depending on the length of the N-terminal region, pentraxins are classified as long or short. Long pentraxins include pentraxin 3 , pentraxin 4 , apexin, neuronal pentraxin 1, neuronal pentraxin 2 , and neuronal pentraxin receptor. Short pentraxins include C-reactive protein (CRP) and serum amyloid P component (SAP).

Pentraxin 3 is produced in response to proinflammatory cytokines (interleukin $1 \beta$, IL- $1 \beta$; tumour necrosis factor alpha, TNF- $\alpha$ ), in the presence of a lipopolysaccharide in response to the anti-inflammatory cytokine IL-10, pathogen fragments (lipopolysaccharide, mycobacterial lipoarabinomannans, Gram-negative bacterial outer membrane protein A) as well as toll-like receptor (TLR) agonists $^{(2)}$. According to reports, IL- 6 and interferon- $\gamma$ do not stimulate the synthesis of this glycoprotein ${ }^{(1)}$.

Literature data indicates that, under physiological conditions, plasma PTX3 levels in adults are $<2 \mathrm{ng} / \mathrm{mL}^{(3)}$. Induction of PTX3 production is already detectable one hour after the stimulus, with a peak between 2 and 6 hours. During endotoxic shock, sepsis and other inflammatory conditions, PTX3 levels increase rapidly up to $200-800 \mathrm{ng} / \mathrm{mL}$ and are correlated with disease severity ${ }^{(3)}$.

Unlike CRP mRNA, which is produced in hepatocytes, PTX3 mRNA is synthesised at the site of the inflammatory reaction, i.e. in endothelial cells, mononuclear phagocytes/macrophages, myeloid dendritic cells, fibroblasts, smooth muscle cells, renal mesangial cells, synovial cells, chondrocytes, adipocytes, alveolar epithelium, glial cells and granulosa cells of the cumulus oophorus ${ }^{(4)}$. Pentraxin 3 is stored in neutrophil granules, which are its main reservoir and which undergo degranulation in acute inflammatory conditions. Pentraxin 3 is synthesised de novo in chronic conditions ${ }^{(4)}$.

Very high levels of blood PTX3, observed immediately after trigger occurrence, are associated with the release of initially formed PTX3 contained in neutrophil granules. Maugeri et al. showed that neutrophil degranulation was responsible for increased serum PTX3 occurring within 6 hours of the onset of clinical symptoms of acute myocardial infarction, and that they returned to

\section{DIAGNOSIS OF FERTILITY DISORDERS AND PREGNANCY PATHOLOGY}

Pentraxin 3 is synthesised before ovulation by the granulosa cells surrounding the oocyte, and it actively participates in the organisation of hyaluronan-rich matrix, which is necessary for fertilisation ${ }^{(6)}$. Pentraxin 3 was detected in the chorion, amniotic epithelium, terminal villi of the trophoblast and the perivascular placental stroma in physiological pregnancies ${ }^{(7)}$. A progressive increase in PTX3 was observed in the course of normal pregnancy ${ }^{(7-9)}$. Studies have shown that plasma PTX3 peaks during labour ${ }^{(7,10)}$. Significantly higher PTX3 levels were observed in women after vaginal birth vs. caesarean section ${ }^{(11)}$.

Significantly elevated maternal serum levels of PTX3 during in vitro embryo transfer have negative effects on embryo implantation ${ }^{(12)}$. Elevated blood PTX3 in the first trimester and in placental tissues is also associated with recurrent pregnancy loss ${ }^{(13,14)}$.

Elevated maternal blood PTX3 may be considered an early marker of placental dysfunction, and it was seen in pathological pregnancies (complicated with pre-eclampsia, gestational diabetes, preterm birth, and premature rupture of membranes) $)^{(7,10,11)}$. It was found in an animal model that the PTX3 ligand, a component of the complement system 1q (C1q), plays a key role in trophoblast invasion and remodelling of spiral arteries, and an abnormal distribution of $\mathrm{Clq}$ is associated with frequent pregnancy loss and premature births ${ }^{(15)}$.

\section{PTX3 IN NEONATES AND CHILDREN}

To date, no reference range for plasma PTX3 has been set for neonates and children. As reported by Galli et al., mean PTX3 levels are $4.28 \mathrm{ng} / \mathrm{mL}$ in children $>1$ year of age, $6.07 \mathrm{ng} / \mathrm{mL}$ in infants, and $11.69 \mathrm{ng} / \mathrm{mL}$ in neonates ${ }^{(16)}$.

There is a significant difference in umbilical cord blood PTX3 between newborns born by caesarean section (mean $13.24 \mathrm{ng} / \mathrm{mL}$ ) and those born vaginally (mean $18.41 \mathrm{ng} / \mathrm{mL})^{(16)}$, which suggests that PTX3 can be included in the group of acute phase proteins.

Serum levels of PTX3 in full-term newborns on day 1 were found to be lower than in newborns aged 3-7 days ${ }^{(17)}$.

Akin et al. showed that increased PTX3 (in the serum collected immediately after birth) in premature neonates (23-36 completed weeks of gestation) of mothers with premature rupture of membranes was associated with a higher prevalence of intraventricular haemorrhage, higher neonatal mortality and longer intensive care $^{(18)}$. Premature newborns with high PTX3 levels were more likely to be diagnosed with respiratory distress syndrome, sepsis, preterm retinopathy, and necrotising enterocolitis ${ }^{(18)}$.

Sciacca et al. showed that PTX3 was significantly higher at 24 hours of life in late preterms with respiratory failure requiring the use of assisted ventilation and oxygen 
concentration in the respiratory mixture $\left(\mathrm{FiO}_{2}>0.8\right)$ compared to marginally preterms with respiratory failure treated with continuous positive airway pressure (CPAP) and requiring oxygen concentration of up to $50 \%^{(19)}$.

It was also demonstrated that PTX3 may be a useful diagnostic marker for pulmonary hypertension ${ }^{(20)}$ and sepsis in full-term neonates ${ }^{(21)}$. Battal et al. assessed peripheral blood cell count and the levels of PTX3, CRP and procalcitonin (PCT) in 301 - and 7-day-old neonates with clinical manifestations of infection. The authors did not show the advantage of PCT and CRP over PTX3 in the diagnosis of sepsis in neonates, with significantly higher PTX3 levels in the study group ${ }^{(21)}$. Sprong et al. showed that elevated PTX3 may be an early marker of septic shock in children with severe meningococcal disease ${ }^{(22)}$.

The role of PTX3 as an important acute phase protein has also been shown in children with Henoch-Schönlein purpura (HSP) $)^{(23,24)}$. It was demonstrated that PTX3 is an early marker of renal damage in children with normal urine tests and normal renal function yet. Furthermore, the authors observed higher PTX3 levels in patients with advanced kidney damage ${ }^{(23)}$. Other authors found a positive correlation between PTX3 and CRP, urine $\beta 2$-microglobulin, microalbuminuria and the amount of protein in the daily urine collection in children with urinary tract infections ${ }^{(24)}$. The authors also showed that PTX3 was a more sensitive predictor of HSP kidney damage than $\mathrm{CRP}^{(24)}$. On the other hand, Becerir et al. observed higher urine PTX3 levels in children with parenchymal damage 3 weeks after acute pyelonephritis compared to healthy children ${ }^{(25)}$.

The role of elevated PTX3 was also reported in other diseases in childhood. Licari et al. assessed blood PTX3 in adolescents with allergic asthma ${ }^{(26)}$. Pentraxin 3 was significantly higher in asthmatic vs. healthy children. Kim et al. assessed PTX3 levels in the sputum from allergic children. It was higher in patients with atopy - with elevated total blood IgE levels. Pentraxin 3 levels positively correlated with the severity of asthma and peripheral and sputum eosinophil counts. The authors suggested that PTX3 sputum levels may be used in the diagnosis and treatment assessment in childhood asthma ${ }^{(27)}$.

\section{CONCLUSIONS}

Pentraxin 3 is a multifunctional protein. The biological function of PTX3 is still not fully defined, especially in the population of newborns and children. Pentraxin 3 may be a marker of an early inflammatory reaction, detectable earlier than CRP; therefore further research to explain its role in inflammatory diseases is needed.

\section{Conflict of interest}

Authors do not report any financial or personal connections with other persons or organisations, which might negatively affect the contents of this publication and/or claim authorship rights to this publication.

\section{References}

1. Breviario F, d'Aniello EM, Golay J et al.: Interleukin-1-inducible genes in endothelial cells. Cloning of a new gene related to C-reactive protein and serum amyloid P component. J Biol Chem 1992; 267: 22190-22197.

2. Garlanda C, Bottazzi B, Bastone A et al.: Pentraxins at the crossroads between innate immunity, inflammation, matrix deposition, and female fertility. Annu Rev Immunol 2005; 23: 337-366.

3. Mantovani A, Garlanda C, Doni A et al.: Pentraxins in innate immunity: from C-reactive protein to the long pentraxin PTX3. J Clin Immunol 2008; 28: 1-13.

4. Giacomini A, Ghedini GC, Presta M et al.: Long pentraxin 3: a novel multifaceted player in cancer. Biochim Biophys Acta Rev Cancer 2018; 1869: 53-63.

5. Maugeri N, Rovere-Querini P, Slavich $M$ et al.: Early and transient release of leukocyte pentraxin 3 during acute myocardial infarction. J Immunol 2011; 187: 970-979.

6. Zhang X, Jafari N, Barnes RB et al.: Studies of gene expression in human cumulus cells indicate pentraxin 3 as a possible marker for oocyte quality. Fertil Steril 2005; 83 Suppl 1: 1169-1179.

7. Rovere-Querini P, Antonacci S, Dell'Antonio G et al.: Plasma and tissue expression of the long pentraxin 3 during normal pregnancy and preeclampsia. Obstet Gynecol 2006; 108: 148-155.

8. Larsson A, Palm M, Helmersson J et al.: Pentraxin 3 values during normal pregnancy Inflammation 2011; 34: 448-451.

9. Garg P, Jaryal AK, Kachhawa G et al.: Estimation of asymmetric dimethylarginine (ADMA), placental growth factor (PLGF) and pentraxin 3 (PTX3) in women with preeclampsia. Pregnancy Hypertens 2018; 14: 245-251.

10. Cruciani L, Romero R, Vaisbuch E et al.: Pentraxin 3 in maternal circulation: an association with preterm labor and preterm PROM, but not with intra-amniotic infection/inflammation. J Matern Fetal Neonatal Med 2010; 23: 1097-1105.

11. Assi F, Fruscio R, Bonardi $C$ et al.: Pentraxin 3 in plasma and vaginal fluid in women with preterm delivery. Br J Obstet Gynaecol 2007; 114: 143-147.

12. Freis A, Von Horn K, Göggl T et al.: Serum levels of pentraxin 3 differ significantly at the time of blastocyst transfer depending on implantation success: a pilot study. Arch Gynecol Obstet 2018; 297: 1565-1570.

13. Ibrahim MI, Harb HM, Ellaithy MI et al.: First trimester assessment of pentraxin-3 levels in women with primary unexplained recurrent pregnancy loss. Eur J Obstet Gynecol Reprod Biol 2012; 165: 37-41.

14. Zeybek S, Tepeli E, Cetin GO et al.: Increased expression of pentraxin 3 in placental tissues from patients with unexplained recurrent pregnancy loss. Balkan J Med Genet 2019; 22: 21-28.

15. Kouser L, Madhukaran SP, Shastri A et al.: Emerging and novel functions of complement protein C1q. Front Immunol 2015; 29: 317.

16. Galli A, Nuccetelli M, Pierini R et al.: PTX3 protein determination in neonatal and in childhood age. Early Hum Dev 2008; 84 Suppl: S144.

17. Lannergård A, Rosenström F, Normann A et al.: Serum pentraxin 3 concentrations in neonates. Ups J Med Sci 2014; 119: 62-64.

18. Akin MA, Gunes T, Coban D et al.: Pentraxin 3 concentrations of the mothers with preterm premature rupture of membranes and their neonates, and early neonatal outcome. J Matern Fetal Neonatal Med 2015; 28: 1170-1175.

19. Sciacca $P$, Betta $P$, Mattia $C$ et al.: Pentraxin-3 in late-preterm newborns with hypoxic respiratory failure. Front Biosci (Elite Ed) 2010; 2: 805-809.

20. Farhadi R, Rafiei A, Hamdamian S et al.: Pentraxin 3 in neonates with and without diagnosis of pulmonary hypertension. Clin Biochem 2017; 50: 223-227.

21. Battal F, Emel Bulut Ö, Ylldırım Ş et al.: Serum pentraxin 3 concentration in neonatal sepsis. J Pediatr Infect Dis 2019; 14: 219-222.

22. Sprong T, Peri G, Neeleman C et al.: Pentraxin 3 and C-reactive protein in severe meningococcal disease. Shock 2009; 31: 28-32. 
23. Yüksel S, Çağlar M, Evrengül $\mathrm{H}$ et al.: Could serum pentraxin 3 levels and IgM deposition in skin biopsies predict subsequent renal involvement in children with Henoch-Schönlein purpura? Pediatr Nephrol 2015; 30: 969-974.

24. Ge W, Wang HL, Sun RP: Pentraxin 3 as a novel early biomarker for the prediction of Henoch-Schönlein purpura nephritis in children. Eur J Pediatr 2014; 173: 213-218.

25. Becerir T, Yüksel S, Evrengül H et al.: Urinary excretion of pentraxin-3 correlates with the presence of renal scar following acute pyelonephritis in children. Int Urol Nephrol 2019; 51: 571-577.
26. Licari A, Marseglia G, De Amici M et al.: Pentraxin 3 and D-dimer in children with asthma: a real-world study. Clin Exp Allergy 2019; 49: 550-551.

27. Kim MJ, Lee HS, Sol IS et al.: Sputum pentraxin 3 as a candidate to assess airway inflammation and remodeling in childhood asthma. Medicine (Baltimore) 2016; 95: e5677. 